\title{
Efficacy of mulching, irrigation and nitrogen applications on bottle gourd and okra for yield improvement and crop diversification
}

\author{
Yih-Chi Tan • Jihn-Sung Lai • K. R. Adhikari • \\ S. M. Shakya • A. K. Shukla • K. R. Sharma
}

Published online: 15 May 2009

(C) Springer Science + Business Media B.V. 2009

\begin{abstract}
An on-farm irrigation trial conducted on the upland of Chitwan valley of Nepal evaluated the amount and frequency of irrigation as well as the effect of nitrogen fertilizer and straw mulch applications on the performance of bottle gourd and okra vegetables. The experiment was laid out on split-split-plot design with fertilizer as main-plot factor, frequencies of irrigation as sub-plot factor, and amount of irrigation as sub-sub-plot factor. Data analysis revealed that frequency and amount of irrigation had a significant interaction effect on the number of nodes that emerge before the opening of the first flower in bottle gourd. Likewise, a significant effect of mulching was observed on the number of primary branches $(P=0.05)$. Number of nodes and primary branches both contributed to higher production of bottle gourd. Results also indicated that frequent application of higher amount of irrigation to bottle gourd could lead to reduced water productivity and suffer from yield losses. In the case of okra, low level of nitrogen application $\left(30 \mathrm{~kg} \mathrm{~N} \mathrm{ha}^{-1}\right)$ with low but daily watering had significantly higher yield $\left(1,365 \mathrm{~g} \mathrm{plot}^{-1}\right)$ than from higher level of nitrogen application $\left(90 \mathrm{~kg} \mathrm{ha}^{-1}\right)(P=0.01)$. Interaction effect of all factors was also significant $(P=0.05)$ on the fruit yield of okra which implied greater value of smaller
\end{abstract}

Y.-C. Tan $(\square)$

Department of Bioenvironmental Systems Engineering, Hydrotech Research Institute,

Disaster Research Center, National Taiwan University, 1 Roosevelt Road Sec 4, Taipei 106, Taiwan e-mail: yctan@ntu.edu.tw

J.-S. Lai

Out-reach Research Program of Hydrotech Research Institute, National Taiwan University, Taipei, Taiwan

K. R. Adhikari

Department of Soil Science and Agricultural Engineering, Institute of Agriculture and Animal Sciences, Tribhuvan University, Rampur, Chitwan, Nepal

S. M. Shakya

Department of Horticulture, Institute of Agriculture and Animal Sciences, Tribhuvan University, Rampur, Chitwan, Nepal

A. K. Shukla $\cdot$ K. R. Sharma

Nepal Engineering College (NEC), Bhaktapur, Nepal 
irrigation to contribute to increased returns to farmers by improving production level of okra in this area of Nepal

Keywords Bottle gourd $\cdot$ Mulching $\cdot$ Nitrogen $\cdot$ Okra $\cdot$ On-farm irrigation $\cdot$ Nepal

\section{Introduction}

Global fruit and vegetable production has increased to 1.34 billion MT in 2003, up from 396 million MT in 1961 (FAO, 2005). Vegetable production is usually lucrative compared to staple crops. Therefore, a relatively large body of the literature deals with poverty outcomes for small farmers from opportunities represented through horticultural trade (Dolan and Humphrey, 2000; Henson et al., 2005, Maertens, 2006).

In the context of Nepal where most farmers lack sufficient resources for profitable food production (Adhikari, 2001), dry season vegetables production such as bottle gourd and okra through cost-effective techniques of irrigation and fertilization seems promising. But decreased water availability during this season has been identified as a constraint on vegetable production. Therefore, apportioned water for agriculture has to be utilized in an efficient and rationalized manner. Two issues that need attention are (1) finding a means of lowering the current level of water use by some efficient water use techniques, and (2) promoting economic return to the farmers in an effort to enhance economic incentives. These can be achieved through increased water productivity and crop diversification with high value crops in the area of rice dominated cropping systems of Nepal. It is thus important to maximize water productivity by evaluating the functional relationship between crop yields, water use, and timed input of irrigation water for broader soil and climatic conditions. This would help in developing more practical irrigation schedules in response to available water supply. Higher water productivity is secured when water is applied to vegetables than to cereal crops because of the market value and increased probability of crop diversity. This is particularly important in a Nepalese context where most of the farmers are small holders and are faced with the situations of vulnerable food insecurity.

Vegetables including bottle gourd and okra are very costly in Nepalese local market during dry and off-season. If grown without reliable irrigation supply during the dry season they usually succumb to large yield losses. However, water use of the crops may be greatly lowered by mulching to conserve soil moisture. This can be an important practical aid in water saving and to minimize the cost of water fees for the resource poor farmers. Increased soil-water storage due to mulching could also help increased availability and uptake of nutrients by plant roots.

The growth of the vegetable market even during the dry season and the improved nutritional awareness of people, have attracted farmers to bring greater areas under vegetable farming in summer and spring seasons in the foot-hill and plain areas of Nepal. However, dry weather during this season creates a condition of water scarcity for many crops requiring frequent irrigation. Several studies reported mulch to conserve soil moisture and improve crop yield (Singh and Gangwar, 1972; Singh et al., 1976).

Likewise, the role of irrigation at proper level and stages of plant growth has great significance in improving the yield (Singh et al., 1990). Padem and Alan (1992), Gupta (1990), Bandel et al. (1980), and Thomas et al. (1970) reported that judicious application of fertilizers in conjunction with proper irrigation is the principal factor affecting the crop yield. Modern farming systems have taken advantages of different sophisticated techniques of irrigation that are based either on assessment of soil moisture depletion or moisture 
tension. However, it is important that simpler techniques using Pan Evaporation and nonrecording rain gauge that are within the reach of small-farmers could be sustainably used in this region. Because of simplicity in use for irrigation, the later is likely to have greater potentials for adoption in farmers' conditions.

The assumption driving this experiment was that although crop plants vary in terms of their water requirements for growth and development, such water requirements however can be met by supplying water corresponding to amounts evaporated from the adjacent land surfaces. We tested this assumption by applying irrigation water at three levels of evaporation. The objectives of this study were to (1) evaluate the effect of frequency and amount of irrigation, and (2) examine the response of bottle gourd and okra vegetables to straw mulch and nitrogen $(\mathrm{N})$ fertilizer applications for a given frequency and amount of irrigation. The research results might be useful for yield improvement and crop diversification, applicable to hot and humid agro-ecological conditions under coarse acid soils of Chitwan valley, Nepal.

\section{Materials and methods}

Salient growth characteristics of bottle gourd and okra vegetables

Bottle gourd (Lagenaria siceraria L.) belongs to Cucurbitaceae family. It is characterized by trailing growth habit, branched tendril, male flowers appear first, fruits are pepo varying greatly in shapes, sizes and color. It thrives well in hot and humid conditions. Higher temperature, long day length, and sun light render more male flowers. It can grow over a wide range of soils but sandy loam soil with good natural drainage and $\mathrm{pH}$ near 6.5 is desirable. Depending on weather condition, seeds are either sown in the pit in the main field directly or nursery grown seedling transplanted. In the case of transplanting, seeds are sown in the poly pots filled with mixture of soil and compost manure and transplanted at four to five true leaf stage. With some variations, seedlings are transplanted with row to row spacing of 1.5 to $2 \mathrm{~m}$, and plant to plant 1-2 m. Vines are allowed to trail on the ground or given staking. Fruits are harvested when they are still tender and of marketable size. Yields vary greatly with variety, season, soil, water and nutrient management practices. Fruits are usually $40-45 \mathrm{~cm}$ long and picked in about two months. Yields are variable $\left(25-27.5 \mathrm{t} \mathrm{ha}^{-1}\right)$. Indian Institute of Vegetable Research (IIVR) of Indian Council of Agricultural Research (ICAR) where this variety was released first (cv. Pusha Summer Prolific Long) recommended to apply fertilizer at a rate of 50-100 kg N, 40-60 kg $\mathrm{P}_{2} \mathrm{O}_{5}$ and $30-60 \mathrm{~kg} \mathrm{~K}_{2} \mathrm{O} \mathrm{ha}^{-1}$.

Okra (Abelmoschus esculentus) belongs to Malvaceae family. It is tall-growing ( 0.9 to $2.1 \mathrm{~m}$ ), warm-season annual erect herb and hairy with three to five lobed leaves. The plants bear 12.5 to $30 \mathrm{~cm}$ pyramidal pods. Usually immature pods ( 2 to $3 \mathrm{in}$. long) are picked for cooking or selling in the market. According to IIVR of ICAR, India the okra variety tested in this experiment (cv. Parbhani Kranti L.) bears medium-long fruits with tender smooth surface at marketable stage. Fruits have a good keeping quality. Average yield is $8.5-11.5 \mathrm{t}$ $\mathrm{h}^{-1}$ in 120 days. The immature pods are also used for pickling, soups, canning and stews or as a fried or boiled vegetable. When flowering, okra also bears ornamental value for backyard garden. North Carolina Cooperative Extension Service (http://www.ces.ncsu.edu/ depts/hort/hil/hil-19.html) reported that okra in general require $60-75 \mathrm{~kg} \mathrm{~N}, 125-175 \mathrm{~kg}$ $\mathrm{P}_{2} \mathrm{O}_{5}$ and $125-175 \mathrm{~kg} \mathrm{~K}_{2} \mathrm{O} \mathrm{ha}^{-1}$. In order to achieve maximum yields, the leaflet suggested the pods be harvested every other day. More recently, research results have shown that plastic mulching increased yields and earlier production. 


\section{Nursery preparation}

A nursery of bottle gourd was raised during March, using two to three seeds per polythene pot of $15 \times 12 \mathrm{~cm}$ in size. Well-decomposed and pulverized manure was applied to the pot. Seeds were placed at 2 to $5 \mathrm{~cm}$ depth in the pots. Regular care and watering was carried out until the seedlings were ready for transplanting. Unlike bottle gourd, generally nursery is not required for growing okra.

Land preparation, transplanting and cultural practices

\section{Bottle gourd}

The land was ploughed and cross-harrowed thrice during the second week of March. The manure was mixed with topsoil of the field pits and basal N, P and K elements were applied at a rate of 50:60:60 $\mathrm{kg} \mathrm{ha}^{-1}$, respectively, before transplanting of the seedlings. These $\mathrm{N}, \mathrm{P}$ and $\mathrm{K}$ rates were the actual elements and not the fertilizer weights. The seedlings grown in the poly pots in nursery were transferred to the field pits $(30 \times 30 \times 30 \mathrm{~cm})$ spaced $2 \times 2 \mathrm{~m}$ apart. While transplanting the seedlings, ball of soil surrounding the root system was kept intact to avoid root injury and to ensure proper growth of the seedlings in the pits after transplantation. One out of two to three healthy plants from each of the poly pot was transplanted into one of the four field pits, thus maintaining four plants per sub-sub plot of $16 \mathrm{~m}^{2}$, and kept a gap of $2 \mathrm{~m}$ in each side of the plot (layout given in Fig. 1). The seedlings were 25 days old when transplanted during April 5-6. In case of failure of some seedling to establish well in the field pits after transplanting, due attention was given to replace the weaker seedlings with the healthier ones from the stock saved in the nursery thus filling the gap. According to the irrigation treatment, all four plants within a sub-sub plot received equal and calculated amount of water from a jar or bucket. As shown in the Fig. 1, the main-plots were surrounded by border plants to avoid the border effect. Care was also given to regular watering until the plants were well established. While $50 \mathrm{~kg} \mathrm{~N} \mathrm{ha}^{-1}$ was applied to pit soils as basal dose at the time of transplanting, remaining $\mathrm{N}\left(40 \mathrm{~kg} \mathrm{ha}^{-1}\right)$ was top dressed 45 days after transplanting for continued supply of $\mathrm{N}$ nutrition to the growing plants.

After establishment of the seedlings, plants were mulched on April 28 in such a way that the area around the plants and the interspaces were covered with $5 \mathrm{~cm}$ thick straw mulch. Not only a sub-sub plot of $16 \mathrm{~m}^{2}$, but the whole main-plot under the mulch treatment was covered by straw uniformly. The area under the main-plot with no mulch treatment was left uncovered. Upon mulching the mulch treatment area, irrigation treatments were imposed beginning the same day. The irrigation application was terminated on May 15. Fruit picking started from May 17 and continued until the middle of July. Yield and yield-attributing characteristics selected for crop performance are listed in Table 1. Crop parameters that were not significantly affected by the treatments are not included in the paper.

\section{Okra}

The field was prepared by two to three cross-harrowing and well rotten compost applied at a rate of $20 \mathrm{t} \mathrm{ha}^{-1} 1$ week before sowing the seed. The main plots received three levels of $\mathrm{N}$ $\left(30,60\right.$ and $\left.90 \mathrm{~kg} \mathrm{ha}^{-1}\right)$. So, depending on the level of $\mathrm{N}$ treatment, okra received three different amounts of $\mathrm{N}$ at basal and at top dressing. As $\mathrm{N}$ was the main plot treatment, the basal dose was applied before the seeds were sown on March 28-29 while the remaining half of $\mathrm{N}$ was top dressed on May 16. Unlike split applications of $\mathrm{N}$, all amounts of $\mathrm{P}$ and $\mathrm{K}$ 


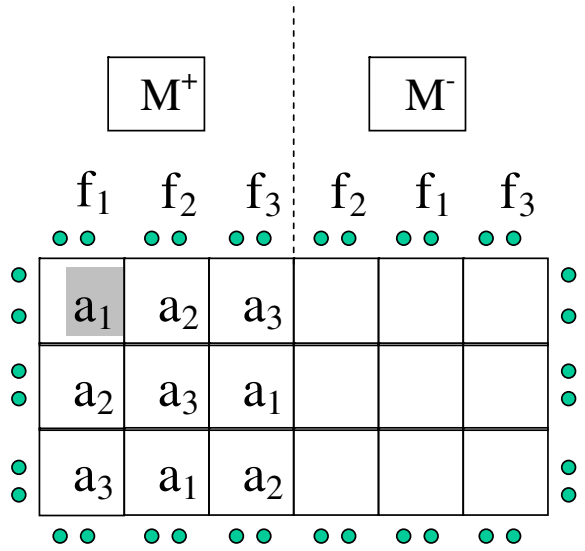

A. Layout of single replication.

' $M$ ' mulching treatment - main plot factor ' $f$ ' frequency of irrigation - sub-plot factor 'a' amount of water - sub-sub plot factor

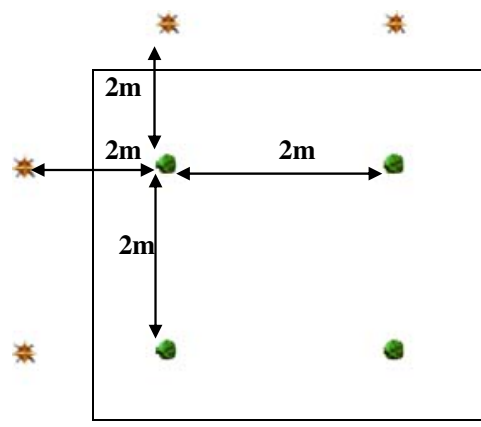

B. Layout of single sub-sub plot at the periphery of the replication
Border plants
- Experimental plants
- Experimental plant of the adjacent sub-sub plot

Fig. 1 Layout of bottle gourd crop

were applied at the time of sowing of seeds, both at the rate of $40 \mathrm{~kg} \mathrm{ha}^{-1}$. Nitrogen, phosphorus and potassium rates as mentioned above were actual nutrient rates and not the amounts of fertilizers. Parbhani Kranti - a variety of okra was used as the test crop. Since okra does not require a nursery, overnight water-soaked seeds were sown directly to the experimental plots on March 28-29. With an area of $2.8 \mathrm{~m}^{2}$ including the area occupied by the border plants, each sub-sub plot consisted of 35 plants in five rows spaced $40 \mathrm{~cm}$ apart. Each row had seven plants spaced $20 \mathrm{~cm}$ apart The net plot consisted of 15 plants, while other 20 in the periphery of a sub-sub plot served as border plants (layout given in Fig. 2). Observations were taken only from those 15 plants grown in the net plot. Irrigation treatments were started from May 3 when the plants were well established and treatments stopped on May 15. Regular watering, gap filling and plant protection measures were carried out as and when needed. Due to the appearance of jassids pest attack, a pesticide 
Table 1 Yield and yield-attributing characteristics selected for measurement

\begin{tabular}{ll}
\hline Bottle gourd & Okra \\
\hline Yield (kg/sub-sub plot) & Yield (gm/sub-sub plot) \\
Number of fruits & Number of fruits \\
Average length of fruits & Length of fruits \\
Average diameter of fruits & Girth of fruits \\
Number of leaves & Plant heights \\
Number of primary branches & Days to $50 \%$ flowering \\
Days to first female flowering & - \\
Number of nodes & - \\
Main shoot length & -
\end{tabular}

called Rogor was sprayed on June 7. Fruits were harvested at an interval of 3-4 days and picked 26 times from May 16 to July 24.

\section{A brief description of the irrigation system used}

In this experiment, a simple "Class-A Evaporation Pan (E-pan)," with $120 \mathrm{~cm}$ diameter made of 22 gage GI sheet (iron sheets galvanized with zinc oxide) was installed in the experimental area. It was quite big and thus was expected to be more reliable in comparison with standard Chinese evaporation pan of $20 \mathrm{~cm}$ diameter and $11 \mathrm{~cm}$ depth popularly used in China and Japan (Yuan et al. 2003; Liu and Kang 2007). An ordinary measuring scale was used to read the decrease in depth of water due to evaporation. The measurement of rainfall was carried out in a $20 \mathrm{~cm}$ diameter non-recording rain gauge installed in the experimental area. Daily observations of E-pan and rainfall were made at 8:00 a.m. After recording the loss of water due to evaporation, E-pan was refilled daily to its marked original water level. Since large part of time in most years, most of the lands are unsaturated with water, the evaporation losses of water from the land surfaces is always lesser than from a natural body saturated with water. Therefore, the values for depletion of water level due to evaporation from E-pan was corrected by multiplying with a pan-coefficient of 0.70 so that it would account for thermal mismatch error. The use of pan coefficient of 0.70 was based on the findings of Michael (1978), and Prihar and Sandhu (1987) who found the Class-A Pan reading to be approximately $30 \%$ higher than the evaporation from a moist soil surface. The total amounts of water applied to bottle gourd $\left(\mathrm{L}\right.$ plant $\left.{ }^{-1}\right)$ and okra $\left(\mathrm{L}\right.$ plot $\left.^{-1}\right)$ are shown in Table 2. Mulitplying the depth of water that is lost by evaporation from an E-pan by 0.70 would equalize the depth of water evaporated from the nearby soil that is saturated (wet) with water.

Water requirement calculation for these crops was based on depletion of water in the Epan in 24-h period. Amount of rainfall was deducted from E-pan reading to determine the rate of effective evaporation. Therefore, amounts of irrigation water applied to the test crops corresponded to effective evaporation. Since the experiment was started during the dry season, Fig. 3 shows that weekly rainfall amounts in the first-half part of growing season were mostly lower than weekly evaporation hence all the rainfall touching the ground during this time was considered effective in terms of contribution to plant water requirement. During the dry season in this area, atmospheric demand for water mostly exceeds the rainfall amounts. Therefore, this assumption of effectiveness should hold reasonably true. However, at times it also cannot be ignored that due to several pathways of rainwater, not all rain that strikes the ground can be considered effective from production 


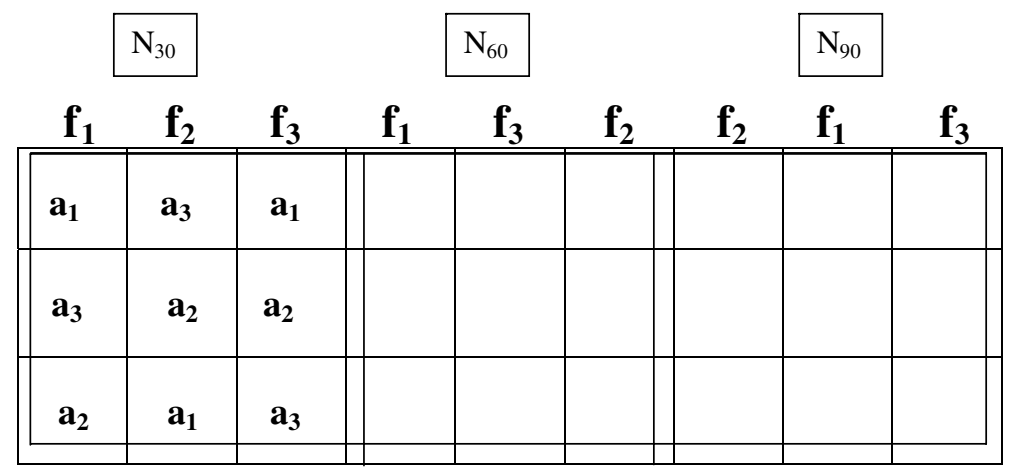

A. Layout of a single replication

' $N$ ' nitrogen levels - main plot factor

'f' frequency of irrigation - sub-plot factor

'a' amount of water - sub-sub plot factor.

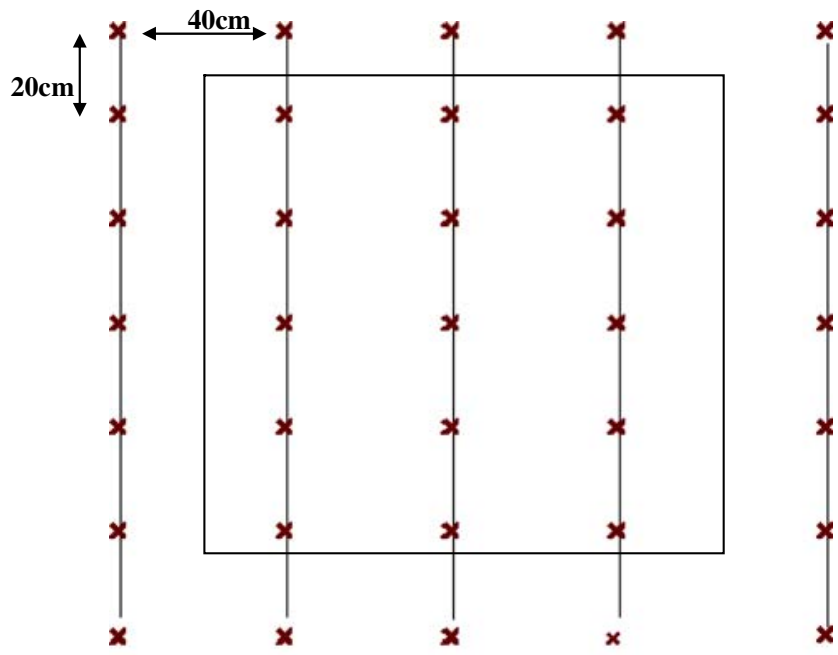

B. Layout of a single sub-sub plot

x Location of okra seedling within a sub-sub plot

Fig. 2 Layout of okra crop

point of view. A simple example of how these quantities were computed for applying water for irrigation in this experiment is illustrated below:

Considering the okra's sub-sub plot of $2.8 \mathrm{~m}^{2}$, lets assume that $10 \mathrm{~mm}$ depth of water was decreased in the E-pan in $24 \mathrm{~h}$.

After correcting for thermal mismatch error, adjusted E-pan value $=10 \mathrm{~mm} \times 0.7=$ $7.0 \mathrm{~mm}$

Assuming that $5 \mathrm{~mm}$ depth of rainfall occurred within the same $24 \mathrm{~h}$, then, Effective evaporation would be equal to $7-5 \mathrm{~mm}=2 \mathrm{~mm}$.

In terms of $\mathrm{m}^{3}$ volume of water per sub-sub plot $=2 / 1,000 \mathrm{~m} \times 2.8 \mathrm{~m}^{2}=0.0056 \mathrm{~m}^{3}$ Assuming that $1 \mathrm{CC}=1 \mathrm{~mL}$ and using the relationship of $1 \mathrm{~m}^{3}$ of a volume corresponds to $1,000 \mathrm{~L}$ of water, 
Table 2 Amount and frequency of irrigation water for bottle gourd and okra

\begin{tabular}{|c|c|c|c|}
\hline \multirow{2}{*}{$\begin{array}{l}\text { Irrigation } \\
\text { Frequency }\end{array}$} & \multirow[t]{2}{*}{ Water Level } & \multicolumn{2}{|c|}{ Amount of irrigation water } \\
\hline & & $\begin{array}{l}\text { Bottle gourd } \\
\text { (litre plant }^{-1} \text { ) }\end{array}$ & $\begin{array}{l}\text { Okra } \\
\text { (litre plot }^{-1} \text { ) }\end{array}$ \\
\hline \multirow[t]{3}{*}{ Daily } & $\mathrm{IW} / \mathrm{E}-\mathrm{pan}=1$ & 73.7 & 140 \\
\hline & $\mathrm{IW} / \mathrm{E}-\mathrm{pan}=0.75$ & 54.1 & 102 \\
\hline & $\mathrm{IW} / \mathrm{E}-\mathrm{pan}=0.50$ & 34.5 & 65.2 \\
\hline \multirow[t]{3}{*}{ Two days interval } & $\mathrm{IW} / \mathrm{E}-\mathrm{pan}=1$ & 71.9 & 139 \\
\hline & $\mathrm{IW} / \mathrm{E}-\mathrm{pan}=0.75$ & 49.3 & 102 \\
\hline & $\mathrm{IW} / \mathrm{E}-\mathrm{pan}=0.50$ & 31.3 & 65.2 \\
\hline \multirow[t]{3}{*}{ Four days interval } & IW/E-pan=1 & 73.7 & 140 \\
\hline & $\mathrm{IW} / \mathrm{E}-\mathrm{pan}=0.75$ & 52.1 & 96.9 \\
\hline & $\mathrm{IW} / \mathrm{E}-\mathrm{pan}=0.50$ & 30.3 & 54.6 \\
\hline
\end{tabular}

Actual amount of water need for okra over the $2.8 \mathrm{~m}^{2}$ surface area $=0.0056 \mathrm{~m}^{3} \times$ $1,000 \mathrm{~L}=5.6 \mathrm{~L}$. This quantity would correspond to treatment of E-pan=1:1 ratio. Similarly, it would be equal to $5.6 \times 0.75 \mathrm{~L}$ for $75 \%$ of E-pan and $5.6 \times 0.5 \mathrm{~L}$ for $50 \%$ of E-pan treatments.

Experimental design, irrigation scheduling and data analysis

The experiment was laid out on a split-split plot design with (1) three levels of amount of irrigation water (AIW) as sub-sub-plot factor, and (2) three frequencies of irrigation application as sub-plot factor. At sub-sub plot and sub-plot level, both crops experiments
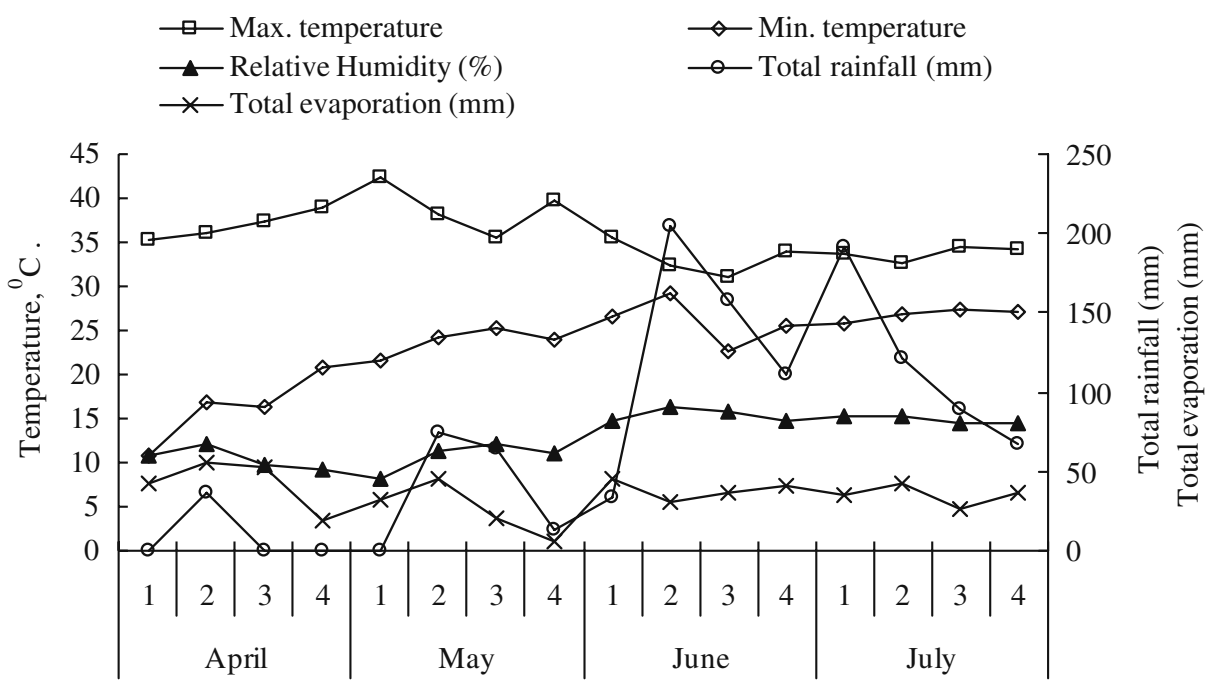

Months by weeks

Fig. 3 Weather conditions during the crop growing season 
were similar to each other in terms of these factors and treatment levels. However, at the main plot level, they received different factors treatments i.e., bottle gourd received mulching (with and without straw mulch), whereas okra received nitrogen fertilization at a rate of 30:60:90 $\mathrm{kg} \mathrm{N} \mathrm{ha}^{-1}$ With four replications, these resulted to a total of 72 observational units in the case of bottle gourd $(4 \times 2 \times 3 \times 3)$ and 108 observational units in the case of okra $(4 \times 3 \times 3 \times 3)$ experiment. Treatments were attributed to the units of observations at random at all levels of precision for both bottle gourd and okra experiments.

The irrigation schedule was established by (1) the frequency of irrigation (applying water daily, 2 days and 4 days intervals between successive irrigations) and (2) the amount of irrigation determined by IW/E-pan as the ratio between a fixed amount of irrigation water (IW) and cumulative open pan evaporation (E-pan) minus rainfall. Three levels of amounts of irrigation were kept at 1.00, 0.75 and 0.50 ratios between IW and E-pan thus accounting for the amount of water applied to be equal to (1) E-pan, (2) $75 \%$ and (3) $50 \%$ of E-pan, respectively.

Analysis of variance (ANOVA) was carried out on the selected crop performance parameters using statistical package MSTATC to determine whether yield and yieldattributing characteristics were significantly affected by the treatments. The test significance is presented at 0.05 and 0.01 probability levels. The least significant difference (LSD) was computed to compare statistical differences in treatment means.

\section{Results and discussion}

Initial soil fertility and growing weather condition

The soil is classified as coarse loamy, Hyperthermic, Micaceous, Typic Haplustoll (Soil Survey Staff, 1999). According to Landon (1984) rating, soil is medium in organic matter $(2.5 \%)$, low in organic carbon $(1.4 \%)$ and total nitrogen $(\mathrm{N})(0.15 \%)$. Soil texture is sandy loam indicating well aeration with good water conductivities, medium to slightly acid $(\mathrm{pH}$ frequently below 6.0), low in phosphorus (P) supply but well drained and positioned on a nearly leveled topography (Khakural et al., 1984). Due to coarse nature of soil, generally frequent irrigation is desirable depending on the growing season and type of crops being grown. A location map of the study area is shown in Fig. 4.

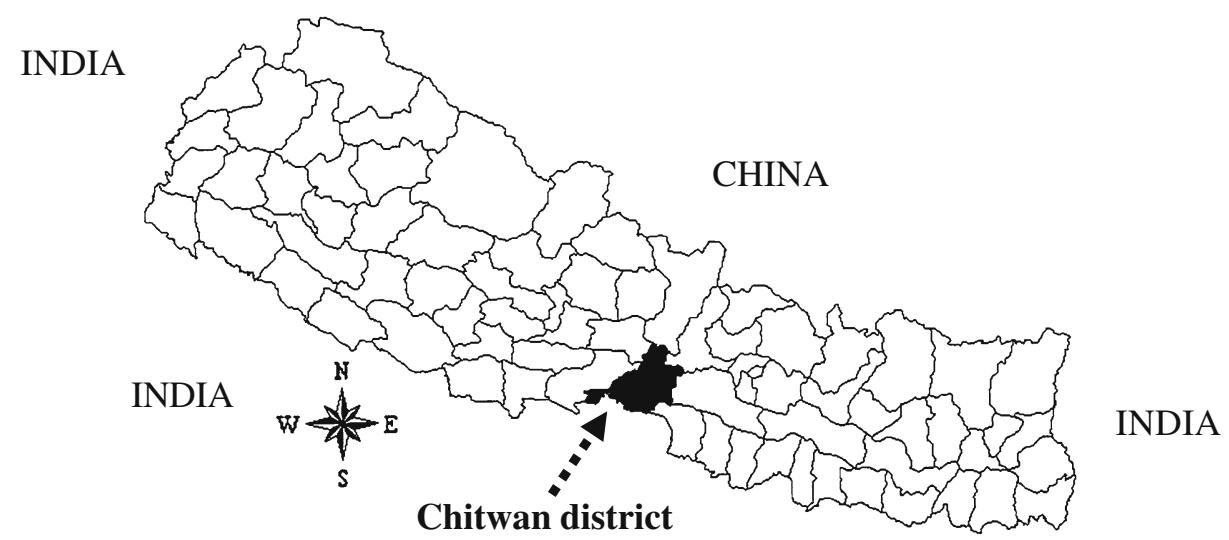

Fig. 4 District map showing location of on-farm irrigation research area in the southern plain of Nepal 
Growing season weather data obtained from a nearby meteorological station and also from Department of Hydrology and Meteorology (2003) are shown in Fig. 3. These data were utilized to understand how growing season weather condition might intervene treatment effects on crop growth and productivities. April and May, were the hottest months, where maximum weekly temperatures ranged from $35^{\circ} \mathrm{C}$ to $40^{\circ} \mathrm{C}$. Minimum temperature increased from a $10^{\circ} \mathrm{C}$ in the first week of April to as high as $30^{\circ} \mathrm{C}$ by the end of May. While rainfall was minimal and evaporation exceeded the rainfall during this firsthalf part of the growing season, hot and dry period prevailed as temperatures were also rising. Since soil dryness increases with temperatures, irrigation treatments under such condition would be expected to leave greater impacts on growing crops. By contrast, with the onset of June until July, rainfall was frequently over $100 \mathrm{~mm}$ every week but evaporation was below $50 \mathrm{~mm}$ indicating increased water storage in soil (Fig. 3). Relative humidity also increased from about $50 \%$ in May to over $80 \%$ in June and July. Increased water storage in the soil clearly indicated that the second-half part of the growing season would be expected to leave not much impact of irrigation treatments on the growth parameters of the test crops.

Figure 3 clearly shows that when rainfall was mostly lower relative to evaporation, from April until the first week of June, supply of irrigation water treatment to the crops was a necessity. After that although temperature and humidity approached a steady-state, occurrence of much higher rainfall led to halt irrigation treatment in this experiment.

\section{Performance of bottle gourd}

Analysis of variance (ANOVA) indicated that main-plot treatment of mulch had a significant effect $(P=0.05)$ on the number of primary branches (Table 3$)$. Generally it is expected that mulch treatment would be superior to no-mulch for improving soil conditions and plant production. But, the result did not keep with the generally held notion that nomulch plots can also give statistically higher number of primary branches (3.47) relative to mulched plots (3.25) (Table 4). The purpose of mulch is primarily to improve soil moisture storage thereby eliminating moisture stress for the growing crops during the dry season and

Table 3 Analysis of variance showing mean squares for yield and yield-attributing characteristics of bottle gourd

\begin{tabular}{lrllc}
\hline Source of variance & DF & No. of primary branches & No. of nodes & Yield \\
\hline Replication & 3 & 0.39 & 7.22 & 290 \\
Mulching $(A)$ & 1 & $0.89^{\mathrm{a}}$ & $0.89 \mathrm{~ns}$ & $188 \mathrm{~ns}$ \\
Error $(a)$ & 3 & 0.037 & 6.26 & 100 \\
Irri interval $(B)$ & 2 & $2.76 \mathrm{~ns}$ & $2.68 \mathrm{~ns}$ & $107 \mathrm{~ns}$ \\
$A \times B$ & 2 & 1.35 & 0.09 & 204 \\
Error $(b)$ & 12 & 1.24 & 7.29 & 72.1 \\
Amt water $(C)$ & 2 & $0.43 \mathrm{~ns}$ & $4.35 \mathrm{~ns}$ & $58.2 \mathrm{~ns}$ \\
$A \times B$ & 2 & 0.35 & 4.35 & 184 \\
$B \times C$ & 4 & 2.12 & 12.9 & 54.8 \\
$A \times B \times C$ & 4 & 1.49 & 0.87 & 20.9 \\
Error $(C)$ & 36 & 1.81 & 3.53 & 60.9 \\
\hline
\end{tabular}

\footnotetext{
${ }^{a}$ Significant at 0.05 probability level, $n s$ non-significant
} 
Table 4 Effect of mulching and frequency and amount of irrigation on yield and yield-attributing characteristics of bottle gourd

\begin{tabular}{llll}
\hline Treatments & No. of fruits & No. of primary branches plant ${ }^{-1}$ & Yield (kg sub-sub plot $\left.{ }^{-1}\right)$ \\
\hline Mulching & 17.1 & $3.25 \mathrm{~b}$ & 25.1 \\
No mulching & 14.6 & $3.47 \mathrm{a}$ & 21.9 \\
SEM & 1.12 & 0.03 & 1.67 \\
LSD at 5\% & $\mathrm{NS}$ & 0.204 & $\mathrm{NS}$ \\
Frequency of irrigation & & \\
Daily & 16.7 & 3.75 & 25.8 \\
2 days & 14.4 & 3.20 & 21.6 \\
4 days & 16.4 & 3.12 & 23.1 \\
SEM & 1.29 & 0.32 & 1.37 \\
LSD at 5\% & $\mathrm{NS}$ & $\mathrm{NS}$ & $\mathrm{NS}$ \\
Amount of irrigation & & & 24.8 \\
IW/Epan=1 & 15.3 & 3.20 & 21.8 \\
IW/Epan=0.75 & 15.5 & 3.42 & 23.8 \\
IW/Epan=0.5 & 16.8 & 3.46 & 1.59 \\
SEM & 1.16 & 0.27 & $\mathrm{NS}$ \\
LSD at 5\% & $\mathrm{NS}$ & $\mathrm{NS}$ &
\end{tabular}

Mean values with the same letter in a column for a given crop parameter are not statistically different $(P=$ 0.05); NS non-significant

also critically helpful for seed germination through increased soil temperature and avoiding surface crust if rain occurs. This experiment however showed different results. This might be because the plots had received a calculated amount of water through irrigation treatments at specified time intervals. The addition of water through rain during the ripening stage of the bottle gourd resulted in equal water content in all plots irrespective of variations in moisture levels due to irrigation treatments. This might explain, among others, as to why the mulched plots could not demonstrate significantly superior effect on bottle gourd performance compared with non-mulched plots.

Although non-significant, mulching had a favorable effect on most of the attributes such as fruit yield, number of fruits, number of leaves, days to first female flowering, and main shoot length. On the other hand, the performance of fruit length, fruit diameter, and number of nodes including number of primary branches was inferior under mulched plots compared to non-mulched plots (because of non-significant effect, data not shown). Ghorai (1995) also had similar results which showed that straw mulch and irrigation application did not have a significant effect on the yield and yield-attributing characteristics of the pointed gourd in similar acid soil. The greater the number of nodes the higher is the possibility of branching to bear more fruits. The node is therefore, considered one of the important yieldattributing characteristics. Mulching is therefore generally considered beneficial for exhibiting positive effects on vegetative characters of the crop.

Amount and frequency of irrigation had a significant effect on the number of nodes. A comparison of treatment means indicated that a moderate amount $(\mathrm{IW} / \mathrm{E}-\mathrm{pan}=0.75)$ of daily irrigation produced the highest number of nodes plant ${ }^{-1}$, which was significantly higher than others treatments (Table 5). The graphical representation shown in Fig. 5 indicated that application of a moderate amount of water on daily basis $((\mathrm{IW} / \mathrm{E}-\mathrm{pan}=0.75)$ might produce 
Table 5 Interaction effect of frequency and amount of irrigation on number of nodes of bottle gourd

\begin{tabular}{llll}
\hline Irrigation interval & \multicolumn{2}{l}{ IW/E-pan (Amount of water, liter) } & \\
\cline { 2 - 4 } & 1 & 0.75 & 0.5 \\
\hline & Number of nodes/plant ${ }^{-1}$ & & $6.8 \mathrm{bc}$ \\
Daily & $5.4 \mathrm{c}$ & $9.0 \mathrm{a}$ & $7.1 \mathrm{abc}$ \\
2 days & $8.1 \mathrm{ab}$ & $6.8 \mathrm{bc}$ & $6.6 \mathrm{bc}$ \\
4 days & $6.7 \mathrm{bc}$ & $6.7 \mathrm{bc}$ & \\
LSD at $5 \%=1.905$ & & & \\
\hline
\end{tabular}

Mean values with the same letter(s) in a column are not statistically different $(P=0.05)$

greater yield. Although daily irrigation of a moderate amount of water produced the highest number of nodes plant ${ }^{-1}$, other biological characteristics of the plant remained statistically similar. This might also imply that a higher number of nodes per se do not guarantee a significant increase in yield and hence suggest that daily irrigation might rather lead to a decrease in water productivity. The frequency and amount of irrigation also had a statistically non-significant effect on all of the response variables other than nodes plant ${ }^{-1}$. Obviously, the question then becomes, why was not irrigation effective in giving rise to a statistically significant yield increase in bottle gourd?

A reason for the non-significant effect of irrigation might be that seedlings were transplanted in sufficiently deep and wide pits of $30 \times 30 \times 30 \mathrm{~cm}$ sizes. As the plants grew, roots proliferated deeper into the loosened subsoil where they could acquire a greater volume of water easily. This might have reduced the effect of applied water on the surface during the early part of the growing season even though the upper part of the soil was still

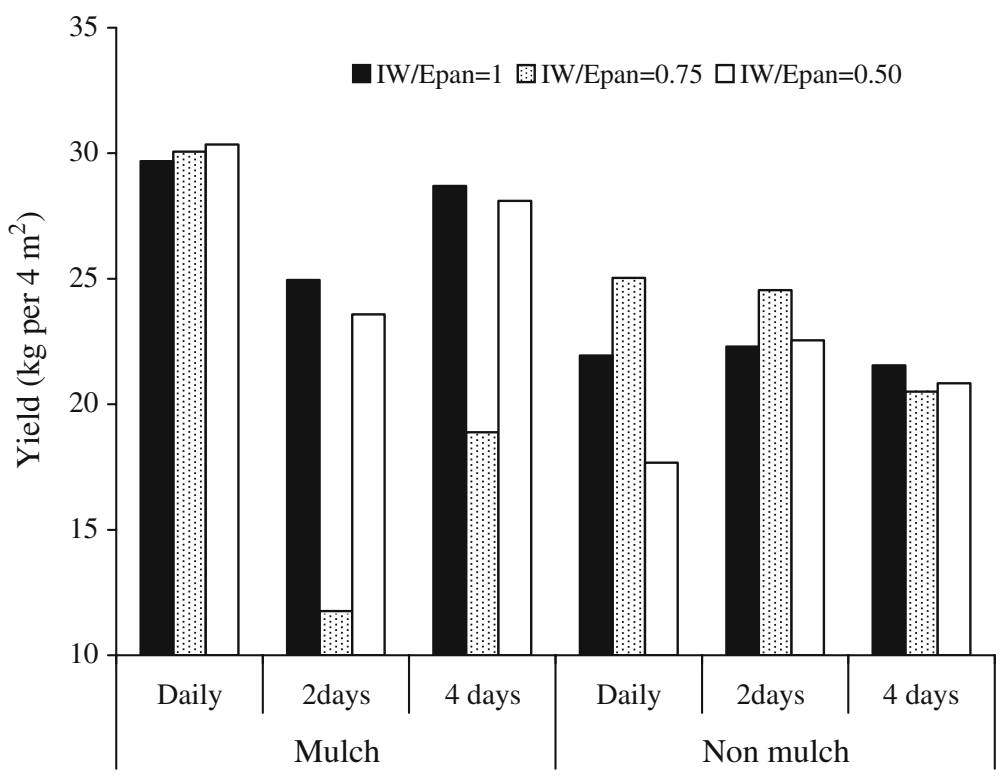

Fig. 5 Effect of mulching, irrigation frequency and amounts of water applications on the yield of bottle gourd 
dry. Related to the later part of the growing season, irrigation treatment was stopped early on May 15 due to onset of rain but the crop continued producing new fruits. As a result, fruit picking continued for about two months even after irrigation treatment was stopped. Growing season weather data (Fig. 3) indicated that when the irrigation was stopped, a period that marked an abrupt increase in rainfall was followed. The intermittent rainfall thereafter also appeared to have contributed to keep the soil moist for the next two months until the end of July. It seems obvious that the onset of monsoon weather might have muddled the effect of irrigation treatment on fruit yields of the bottle gourd. Therefore the outcome of non-significant fruit yields between treatments could be attributed neither to irrigation nor to time effect before or after monsoon rain that was set up from the middle of the growing season. A lesson was learnt that in order to arrive at a conclusive result, a similar experiment needs to be carried out where the crop is allowed to grow, mature and harvest before the onset of the monsoon season.

\section{Performance of Okra}

Analysis of Variance (ANOVA) indicated that $\mathrm{N}$ had highly significant $(P=0.01)$ effect on the yield of okra (Table 6). The mean yields (1,364 and 1,238 g sub-sub-plot $\left.{ }^{-1}\right)$ obtained by applying $\mathrm{N}$ at 30 and $60 \mathrm{~kg} \mathrm{ha}^{-1}$, respectively were statistically similar to each other but were significantly greater than the yield $\left(1,044 \mathrm{~g} \mathrm{sub}^{-} \mathrm{sub}\right.$ plot $\left.^{-1}\right)$ obtained by applying $\mathrm{N}$ at $90 \mathrm{~kg} \mathrm{ha}^{-1}$ (Table 7). Higher yields from lower levels of $\mathrm{N}$ may partly be attributed to the relationships of $\mathrm{N}$ with other soil nutrients, especially available soil phosphorus (P) for plants uptake. Phosphorus availability is decreased with an increase in $\mathrm{N}$ level in the soil (Tisdale et al, 1993). Therefore, given the condition that water was not a limiting factor in the soil, higher yield from lower level of $\mathrm{N}$ might be thought of due to, among others, efficient utilization of soil $\mathrm{P}$ by the growing crops. Phosphorus being a major soil nutrient, it is critical to all crops including okra since it offers essentially a fundamental site for energy transfer and metabolic functions in all plant system. The fact that the experiment did not consider the $\mathrm{N}$ treatment in relation to other nutrient elements in the soil might also be considered a design defect in this research. While there is sufficient native supply of potassium in the soils of this region, $\mathrm{P}$ deficiency is a frequent phenomenon for $\mathrm{P}$ demanding crops due to soil

Table 6 Analysis of variance showing the mean square values for yield and yield-attributing characteristics of okra

\begin{tabular}{lrrll}
\hline Source of variance & DF & \multicolumn{1}{l}{ Yield } & Plant height $(\mathrm{cm})$ & Days to $50 \%$ flowering \\
\hline Replication & 3 & $1,800,056$ & 321 & 169 \\
Nitrogen $(A)$ & 2 & $940,486^{\mathrm{a}}$ & $334 \mathrm{~ns}$ & $17.6 \mathrm{~ns}$ \\
Error $(a)$ & 6 & 74,227 & 157 & 47.2 \\
Irrigation interval $(B)$ & 2 & $321,407 \mathrm{~ns}$ & $533 \mathrm{~ns}$ & $22.5 \mathrm{~ns}$ \\
$A \times B$ & 4 & 270,129 & 244 & 62.1 \\
Error $(b)$ & 18 & 149,344 & 182 & 53.3 \\
Amount of water $(C)$ & 2 & $71,402 \mathrm{~ns}$ & $78.2 \mathrm{~ns}$ & $16.3 \mathrm{~ns}$ \\
$A \times B$ & 4 & 50,644 & 47.3 & 21.7 \\
$B \times C$ & 4 & 54,708 & 60.6 & 42.4 \\
$A \times B \times C$ & 8 & $237,489^{\mathrm{b}}$ & 88.7 & 25.9 \\
Error $(C)$ & 54 & 93,914 & 61.7 & 16.9 \\
\hline
\end{tabular}

\footnotetext{
a b Significant at 0.01 and 0.05 probability level, respectively, $n s$ non-significant
} 
Table 7 Effect of nitrogen rates, and frequency and amount of irrigation on the yield and yield-attributing characteristics of okra

\begin{tabular}{llll}
\hline Treatments & Yield $\left(\mathrm{g}\right.$, sub-sub plot $\left.^{-1}\right)$ & Plant height $(\mathrm{cm})$ & Days to 50\% flowering \\
\hline Nitrogen $(\mathrm{N})\left(\mathrm{Kg} \mathrm{ha}^{-1}\right)$ & & & \\
N30 & $1,364 \mathrm{a}$ & 47.7 & 71.6 \\
N60 & $1,238 \mathrm{a}$ & 52.8 & 72.8 \\
N90 & $1,044 \mathrm{~b}$ & 47.4 & 72.9 \\
SEM & 45.4 & 2.09 & 1.14 \\
LSD at 5\% & 157 & $\mathrm{NS}$ & $\mathrm{NS}$ \\
Frequency of irrigation & & & \\
Daily & 1,315 & 46.1 & 71.7 \\
2 days & 1,204 & 53.6 & 72.3 \\
4 days & 1,127 & 48.3 & 73.3 \\
SEM & 64.4 & 2.25 & 2.10 \\
LSD at 5\% & $\mathrm{NS}$ & $\mathrm{NS}$ & $\mathrm{NS}$ \\
Amount of irrigation & & & 71.7 \\
IW/E-pan=1 & 1,266 & 47.7 & 72.8 \\
IW/E-pan=0.75 & 1,185 & 49.7 & 72.8 \\
IW/E-pan=0.5 & 1,195 & 50.6 & 0.68 \\
SEM & 51.1 & 1.30 & NS \\
LSD at 5\% & $\mathrm{NS}$ & $\mathrm{NS}$ & \\
\hline
\end{tabular}

Mean values with the same letter(s) in a column for $\mathrm{N}$ rates are not statistically different $(P=0.05)$

NS non-significant

acidification in most parts of Nepal (Subedi et al., 1989; Tripathi, 1999). Low soil P supply with the soils in the study area was also reported by a soil survey (Khakural et al., 1984).

Furthermore, though lower level of $\mathrm{N}$ increased okra yield significantly, all yieldattributing characteristics such as plant height, days to $50 \%$ flowering, number of fruits and fruit girth could not respond significantly to the application of $\mathrm{N}$ fertilizer (non-significant data not shown). It could be that the cumulative effect of $\mathrm{N}$ nutrition on these attributes was significant in increasing the crop yield.

With regard to the issue of irrigation, although single effects of frequency and amount of irrigation were observed to be non-significant on any of the response variables, an interaction of these, when combined with nitrogen was found to be significant $(P=0.05)$ in increasing the yield of okra (Table 6). A comparison of treatment mean values revealed two

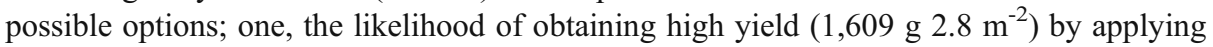
shallow irrigation $(\mathrm{IW} / \mathrm{E}-\mathrm{pan}=0.5)$ on a day-to-day basis which still kept the level and cost of nitrogen low, i.e., $30 \mathrm{~kg} \mathrm{ha}^{-1}$ (Fig. 6, Table 8); two, if the grower wanted to irrigate a field at wider time intervals without losing fruit yield while keeping the $\mathrm{N}$ cost low, water application at 4 days interval could be an appropriate alternative. The results showed that in both of these situations, the yield of okra obtained was statistically similar.

From the foregoing discussions, it seems that okra and bottle gourd vegetable crops responded to the treatments in quite different ways. This variation was explained to a limited extent in this paper but it also appears obvious that there is a need to further evaluate their differences due to physiological characteristics of the plant, and the field conditions they are exposed to during growing seasons. For instance, overnight soaked okra 


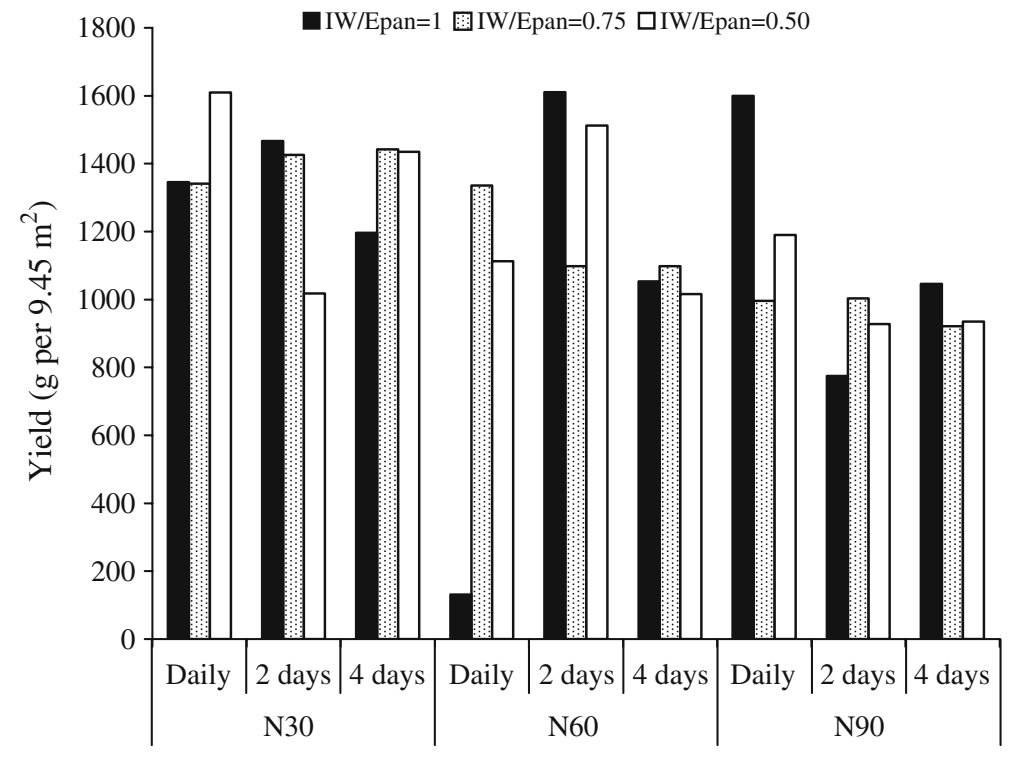

Nitrogen application rate, $\mathrm{kg} \mathrm{ha}^{-1}$

Fig. 6 Effect of nitrogen rate, irrigation frequency and amounts of water application on the yield of okra

Table 8 Treatment means for interaction effect of $\mathrm{N}$ rate, frequency and amount of irrigation on the yield of okra

\begin{tabular}{|c|c|c|c|c|}
\hline \multirow[t]{2}{*}{ Nitrogen $\left(\mathrm{kg} \mathrm{ha}^{-1}\right)$} & \multirow[t]{2}{*}{ Irrigation interval } & \multicolumn{3}{|c|}{ IW/Epan (Amount of water, liter sub-sub plot ${ }^{-1}$ ) } \\
\hline & & 1 & 0.75 & 0.5 \\
\hline & & \multicolumn{3}{|c|}{ yield (g sub-sub plot ${ }^{-1}$ ) } \\
\hline N30 & Daily & 1,345 abcdefg & 1,341 abcdefg & $1,609 \mathrm{a}$ \\
\hline N30 & 2 days & $1,467 \mathrm{abc}$ & 1,425 abcdef & 1,018 defgh \\
\hline N30 & 4 days & 1,196 abcdefgh & 1,442 abcd & 1,434 abcde \\
\hline N60 & Daily & 1,305 abcdefg & 1,335 abcdefg & 1,112 bcdefgh \\
\hline N60 & 2 days & $1,610 \mathrm{a}$ & 1,098 bcdefgh & $1,512 \mathrm{ab}$ \\
\hline N60 & 4 days & 1,053 cdefgh & 1,098 bcdefgh & 1,015 befgh \\
\hline N90 & Daily & $1,599 \mathrm{a}$ & $995 \mathrm{fgh}$ & 1,189 abcdefgh \\
\hline N90 & 2 days & $775 \mathrm{~h}$ & 1,003 efgh & $928 \mathrm{gh}$ \\
\hline N90 & 4 days & 1,045 cdefgh & $921 \mathrm{gh}$ & $935 \mathrm{gh}$ \\
\hline LSD at $5 \%=434.4$ & & & & \\
\hline
\end{tabular}

Mean values with the same letter(s) within a column for a given amount of water applied are not statistically different $(P=0.05)$

Size of one sub-sub plot $=2.8 \mathrm{~m}^{2}$

Yields expressed as fresh weights of the pods/plot 
seeds were sown directly to the top-soil without making a pit. Because of the existence of plough pan underneath in the experimental site, these plants grown on the loosened shallow surface soils might have been influenced more by treatments of added water. This is because sub-surface stored water could not be readily available for the plants unless plough pan is broken through some means of sub-soiling. On the other hand, bottle gourd seedlings prepared in polyethylene pots were transplanted to sufficiently deep and wide pits filled with well rotted manure and fertile soil where plough pan were broken completely. Bottle gourd plants therefore developed extensively thick and bushy vegetative growth. It is also likely that too much vegetative growth of bottle gourd affected adversely on fruit bearing ability of the plant. Furthermore, some errors might have also occurred in data recording of bottle gourd during fruit picking under heavily intermingled vines that posed difficulty in identifying which fruits belonged to plants of which experimental plots.

\section{Conclusions}

While irrigation has been recognized as a key production function in improving crop productivity, the effect of frequency and amount of irrigation as observed in this experiment did not appear to be effective in producing statistically significant yields of bottle gourd. However, signs of yield increase were evident with these treatments but further study is warranted to quantify an appropriate amount and frequency of irrigation for producing significantly higher yield of bottle gourd. Mulching is considered an effective way to conserve soil-water, its effects on bottle gourd in this experiment, however, was greatly masked as intervened by the onset of the monsoon while the crop was still in the field. Keeping the beneficial effects of mulch on soil properties aside, the result suggested that mulching might not be necessary when irrigation is available at low cost or rain occurs to break the dry season effect under the similar agro-ecological conditions. Okra demonstrated highly significant fruit yield increases with the lowest nitrogen level $\left(30 \mathrm{~kg} \mathrm{ha}^{-1}\right)$, which might have been due to an efficient utilization of soil nutrients when irrigation treatments removed the condition of moisture stress in the soil. This was evident from the significant interaction of applied $\mathrm{N}$ with the frequency and amount of irrigation. This signaled that frequent but shallow irrigation would be more beneficial for okra production under similar soils and agro-ecological conditions of Rampur, Chitwan, Nepal.

Acknowledgements The authors would like to thank the Research and Training Development Branch of the Department of Irrigation, Government of Nepal for financial support for this work. The Water Management Study Program at the Institute of Agriculture and Animal Sciences, Tribhuvan University, Rampur, Chitwan, Nepal which provided a venue for on-farm irrigation research site, data analysis and computing facilities is highly commendable. Mr. Bijay Kumar Singh, a freelancer forest specialist in Kathmandu, Nepal is credited for his great help.

\section{References}

Adhikari KR (2001) Diagnosis of the East Rapti River Basin of Nepal. In Proceedings of the regional workshop on integrated water resources management in a river-basin context. Bryan B, Samad MD, Bandaragodaand DJ (ed). Malang, Indonesia, 15-25 January 2001 
Bandel VA, Dziemia S, Standford G (1980) Comparison of nitrogen fertilizer for no-till corn. J Agron 72:334-337

Department of Hydrology and Meteorology (2003) Climatological records of Nepal (1991-1998). Government of Nepal, Kathmandu

Dolan CS, Humphrey J (2000) Governance and trade in fresh vegetables: the impact of UK supermarkets on the African horticulture industry. J Dev Stud 37(2000):147-176

FAO (2005) FAOSTAT data. Accessed November 2004, http://www.fao.org.

Gupta A (1990) Response of spring planted okra to varying levels of irrigation and plant spacing. J Veg Sci $17: 16-19$

Ghorai AK (1995) Effect of straw mulch and different levels of irrigation on the yield and yield components of pointed gourd (Trichosanthes dioica L.). J Veg Sci 22:95-97

Henson S, Masakure O, Boselie D (2005) Private food safety and quality standards for fresh produce exporters: The case of Hortico Agrisystems, Zimbabwe. Food Policy 30(2005):371-384

Khakural BR, Joshi JR, Foth HD (1984) Mapping and characterization of Institute of Agriculture and Animal Science (IAAS) farm soils, Rampur, Chitwan. A land survey report published by IAAS. Tribhuvan Univeristy, Rampur, Chitwan, Nepal

Landon JR (1984) Booker Tropical Soil Manual: A handbook for soil survey and agricultural land evaluation in the tropics and subtropics. Published in the USA by Longman Inc,

Liu HJ, Kang Y (2007) Sprinkler irrigation scheduling of winter wheat in the north China plain using a $20 \mathrm{~cm}$ standard pan. Irrig Sci 25:149-159. doi:10-1007/s00271-006-0042-z

Maertens M (2006) High value supply chains, food standards and poor farmers in developing countries: The case of vegetable exports from Senegal. In selected paper prepared for presentation at the American Agricultural Economics Association Annual Meeting, Long Beach, California (July 23-26)

Michael AM (1978) Irrigation theory and practices. Vikas Pub. House, New Delhi

Padem H, Alan R (1992) The effect of N rates and irrigation levels on growth, yield and nutrient content of cabbage. J Veg Sci 19:121-125

Prihar SS, Sandhu BS (1987) Irrigation of field crops: Principles and Practices. Indian Council of Agricultural Research, New Delhi, India

Singh K, Gangwar RP (1972) Effect of mulching in the production of potato. Journal of Haryana Horticultural Science 1:39-45

Singh K, Vashistha RN, Pandita ML, Batra BR (1976) Effect of mulching on growth, and yield of cucurbits under rain fed condition. Journal of Haryana Horticultural Science 5:87-91

Singh J, Pandey UC, Kohli VP (1990) Response of vegetable pea to irrigation. J Veg Sci 17:11-15

Soil Survey Staff (1999) Soil Taxonomy: A basic system of soil classification for making and interpreting soil surveys, 2nd ed. USDA-NRCS. Agricultural Handbook 18. U.S. Govt. Printing Office, Washington, $\mathrm{DC}$

Subedi KD, Gurung GB, Poudel RS, Gurung KD, Gurung DB, Gurung JB (1989) Traditional methods of maintaining soil fertility in the mid-hills $(1200-2100 \mathrm{~m})$ of the western development region of Nepal (Kaski and Lamjung districts): Problems and potentials. Lumle Agricultural Research Center (LARC) working paper No. 3, Kaski, Nepal

Tisdale SL, Nelson WL, Beaton JD, Havlin JH (1993) Soil Fertility and Fertilizers, 5th edn. MacMillan, NY

Thomas JR, Mamken LN, Brown RG (1970) Yield of cabbage in relation to nitrogen and water supply. Journal of American Society of Horticultural Science 95:732-735

Tripathi BP (1999) Review of acid soils and its management in Nepal. Lumle seminar paper No. 99/1. Lumle Agricultural Research Center (LARC), Kaski, Nepal

Yuan b, Nishiyama S, Kang Y (2003) Effects of different irrigation regimes on the growth and yield of drip irrigated potato. Agri Water Manage 63:153-167. doi:10.1016/S0378-3774(03)00174-4 